\title{
Communication gaps between physicians and patients with postherpetic neuralgia: results from a national study on practice patterns
}

This article was published in the following Dove Press journal:

Journal of Pain Research

8 December 201I

Number of times this article has been viewed

\author{
Terry A Glauser' \\ Gregory D Salinas' \\ Holder Nevins' \\ J Chad Williamson' \\ Mark S Wallace ${ }^{2}$ \\ Maziar Abdolrasulnia \\ 'CE Outcomes, Birmingham, AL, \\ ${ }^{2}$ Department of Anesthesiology, \\ University of California San Diego \\ School of Medicine, La Jolla, CA, USA
}

Correspondence: Gregory D Salinas 107 Frankfurt Circle, Birmingham, AL 3521I, USA

Tel +I 2052591500

Fax + | 205259 |50|

Email greg.salinas@ceoutcomes.com
Background: The purpose of this study was to identify differences in perceptions of care regarding postherpetic neuralgia, including communication patterns between patients and physicians and levels of satisfaction with therapies and care.

Methods: A survey was developed for physicians (neurologists, internists, and family physicians) and patients with postherpetic neuralgia in order to determine their perspectives on its management.

Results: A total of 142 eligible patient respondents were included in the study, and responses were compared with those of 150 primary care physicians and 76 neurologist respondents. Few patients and physicians indicated satisfaction with the currently available treatments for postherpetic neuralgia. While nearly all physicians responded that they discuss the cause of postherpetic neuralgia with a patient, one in four patients indicated that their physician did not discuss the cause. Similarly, one in four patients were not aware of the duration of postherpetic neuralgia, the treatment side effects, or what to expect from treatment. Patients may be less likely to discuss treatment side effects and quality of life issues than physicians perceive.

Conclusion: Physicians and patients have similar perceptions regarding treatment options for postherpetic neuralgia; however, certain gaps in communication were evident, which may be attributable to physician knowledge and communication skills with patients. Strategies to improve issues of expected outcomes and side effects of treatment may be useful to physicians.

Keywords: postherpetic neuralgia, pain, patient communication, case vignette

\section{Introduction}

Herpes zoster, a generally localized, painful rash, is the reactivation of latent varicella zoster virus that has been dormant in the spinal ganglia or cranial sensory nerves since the primary infection. ${ }^{1}$ Approximately one in three individuals in the US will experience herpes zoster in their lifetime, and the risk increases with age. ${ }^{2}$ Annually, there are approximately one million new cases in the US. ${ }^{2}$ When pain associated with herpes zoster persists for more than 3 months beyond resolution of the rash, it is termed postherpetic neuralgia. ${ }^{3}$ Postherpetic neuralgia results from both inflammation and viral damage to peripheral and central axons in sensory neurons, dorsal horn atrophy, and peripheral and central sensitization. ${ }^{1,4}$ Postherpetic neuralgia occurs in $10 \%-18 \%$ of individuals with herpes zoster, and $48 \%$ are still symptomatic at one year. ${ }^{2,3}$ The pain of postherpetic neuralgia may vary from mild to severe and may be intermittent or constant. ${ }^{2}$ It adversely impacts quality of life, causing disruption to sleep, daily activities, and work. ${ }^{5}$ 
In 2004, the Quality Standards Subcommittee of the American Academy of Neurology published an evidencebased practice parameter for the management of postherpetic neuralgia. ${ }^{3}$ Pharmacologic agents recommended by the American Academy of Neurology for the management of postherpetic neuralgia include gabapentin, pregabalin, tricyclic antidepressants, opioids, and topical lidocaine patches. Although this document provides guidance with respect to choice of agents, no recommendations are made for sequence or combination of use. Despite the number of options available, management remains complex, with no one medication addressing the multiple pain pathways active in postherpetic neuralgia. Most patients require use of more than one agent. ${ }^{1}$ While the use of two or more agents allows for greater pain relief at lower doses of each individual drug (and potentially fewer adverse effects), it also increases the risk of drug interactions and decreased patient adherence. ${ }^{1}$

Recent research has found that a substantial fraction of patients with postherpetic neuralgia are not treated as suggested in the American Academy of Neurology guidelines, receiving nonrecommended agents and/or subtherapeutic doses, and, for many, treatment is ineffective. ${ }^{6}$ A survey of internists and family practitioners found the median number of yearly patient visits for postherpetic neuralgia recalled by these physicians was four; most $(>60 \%)$ of these patients were referred for specialty care, with $30 \%$ referred to neurologists. ${ }^{7}$

In order to determine the informational needs of physicians managing patients with postherpetic neuralgia, we designed the multifaceted BASIK (Barriers, Attitudes, Skills, Identified gaps, and Knowledge) postherpetic neuralgia study. Components of this study included examining both physician and patient perceptions on the management of postherpetic neuralgia. Here, we describe key gaps between these perceptions.

\section{Materials and methods}

\section{Survey development and distribution}

In order to develop a survey that provides insight into the issues faced by physicians managing patients with postherpetic neuralgia, a literature review of previously published studies examining gaps in the management of patients with postherpetic neuralgia by US-based primary care physicians and neurologists was conducted. The studies were published between 2000 and 2009, and the literature review was conducted in November 2009. The BASIK postherpetic neuralgia survey was developed from this research. Case-vignette survey development began with the neurologist version of the survey. This survey was reviewed by two US-practicing neurologists in order to determine accuracy and relevance to the neurologist audience. Once the neurologist survey tool was complete, this survey was adapted to fit the scope of practice of primary care physicians and was again reviewed by two US-practicing primary care physicians before distribution.

In November 2009, email invitations to participate in the physician case-vignette surveys were sent to a nationally representative random sample of 450 US primary care physicians and 225 US neurologists, obtained from the American Medical Association Masterfile, 2008. Inclusion criteria for physician participation were that they must be currently practicing and see at least one patient with postherpetic neuralgia per week.

A patient survey was created in conjunction with the physician survey to assess patient pain intensity, level of agreement with statements regarding their postherpetic neuralgia management, types of medications prescribed, and satisfaction with prescribed medications and care. Question types included multiple-choice and 7-point Likert scale rating questions. The patient survey was submitted and approved by the Western Institutional Review Board (Olympia, WA) in October 2009. The patient survey was launched during December 2009 and January 2010 as an online-survey questionnaire and was made available to patients with postherpetic neuralgia who visited the shingles website at WebMD (http://www.webmd.com/ skin-problems-and-treatments/shingles/default.htm). Patients meeting the defined inclusion criteria were given the opportunity to complete the survey. The inclusion criteria were as follows: patients must have been 18 years of age or older, reside in the US, have been diagnosed with herpes zoster, have had pain that remained after the shingles rash went away (remaining pain lasting 6 months or longer), and were prescribed medication for the pain. The survey elements included in the portions of the study focused on in this paper can be found in Appendix A and Appendix B.

\section{Statistical analysis}

Data were first summarized by frequencies (PASW Statistics 18; SPSS Inc, Chicago, IL). In order to compare physician and patient responses, rating scale questions were transformed into categorical variables containing three levels where the mid-point was defined as neutral. 
Pearson's Chi-square analysis was used to compare the responses between physicians and patients. Significance was established at $P<0.05$.

\section{Results}

\section{Physician survey}

The physician responses from the BASIK postherpetic neuralgia study were collected during November 2009. The response rate for the physician surveys was approximately $36 \%$. Two hundred and thirty-five responses (78 neurologists and 157 primary care physicians) were collected, and nine (two neurology respondents and seven primary care physician respondents) were excluded because they did not see patients with postherpetic neuralgia. The final sample contained 76 neurologists and 150 primary care physicians (Table 1 ). The physician sample from the BASIK postherpetic neuralgia study sample showed that primary care physicians reported seeing, on average, 116 patients per week, with an estimated $4 \%$ of their patients having postherpetic neuralgia. Neurologists reported seeing, on average, 86 patients per week, with an estimated $4 \%$ of their patients having postherpetic neuralgia. This translates to about five and three patients per week seen with postherpetic neuralgia, respectively.

\section{Patient survey}

One hundred and forty-two patient responses were collected during December 2009 and January 2010 (Table 2). A response

Table I Demographics of physician sample

\begin{tabular}{lll}
\hline & PCP & Neurologist \\
& $\mathbf{n = 1 5 0}$ & $\mathbf{n = 7 6}$ \\
\hline Gender, percent male & $72 \%$ & $79 \%$ \\
Years in practice, mean (SD) & $23(12)$ & $23(8)$ \\
Specialty & & \\
Family practice & $44 \%$ & - \\
Internal medicine & $56 \%$ & - \\
Practice location & & \\
Urban & $32 \%$ & $26 \%$ \\
Suburban & $50 \%$ & $61 \%$ \\
Rural & $18 \%$ & $13 \%$ \\
Present employment & & \\
Independent & $29 \%$ & $41 \%$ \\
Group & $64 \%$ & $50 \%$ \\
Other* & $7 \%$ & $9 \%$ \\
Patients seen per week, mean (SD) & $116(57)$ & $86(52)$ \\
Patients seen per week with & $5(13)$ & $4(4)$ \\
PHN, mean (SD) & & \\
\hline Pote: & &
\end{tabular}

Note: *"Other employment" includes medical school, health maintenance organization, government, and nongovernment hospitals.

Abbreviations: SD, standard deviation; PHN, postherpetic neuralgia; PCP, primary care physician.
Table 2 Demographics of patient sample

\begin{tabular}{ll}
\hline & Patients \\
& $\mathbf{n}=\mathbf{1 4 2}$ \\
\hline Gender, percent male & $29 \%$ \\
Age & \\
$40-49$ years & $20 \%$ \\
$50-59$ years & $36 \%$ \\
$60-69$ years & $20 \%$ \\
$70-79$ years & $13 \%$ \\
Currently receiving treatment or medication for pain & $67 \%$ \\
Race/ethnicity & \\
White, not of Hispanic origin & $86 \%$ \\
Black or African American, not of Hispanic origin & $9 \%$ \\
Hispanic & $2 \%$ \\
Highest grade completed Grade I2 or GED & $20 \%$ \\
College or technical school I-3 years & $47 \%$ \\
College 4 or more years or college degree & $13 \%$ \\
Graduate school I or more years & $16 \%$ \\
Patient's pain rating at its worst*, mean (SD) & $9.3(1.7)$ \\
Patient's pain rating time of survey, mean (SD) & $5.8(2.4)$ \\
Prescribing physician & \\
Family physician & $62 \%$ \\
Internist & $16 \%$ \\
Neurologist & $7 \%$ \\
Pain specialist & $5 \%$ \\
Other** & $9 \%$ \\
\hline Notes & \\
\hline
\end{tabular}

Notes: *Pain rated on I-10 scale, with 10 indicating highest; *** "other prescribers" includes emergency physician, dermatologist, or infectious disease specialist. Abbreviation: SD, standard deviation.

rate for the patient survey was unattainable due to the fact that participants were not emailed an invitation to participate; rather, they were invited to participate via a link on the shingles website at WebMD. The majority of patient respondents were white non-Hispanic (86\%) females $(71 \%)$ aged $50-59$ years (36\%) with 1-3 years of college or technical education and currently receiving treatment or medication for pain (67\%). Patients reported a mean pain rating of 9.34 on a 10-point rating scale when the pain from their postherpetic neuralgia was at its worst and current mean pain rating of 5.79.

\section{Physician-patient communication about postherpetic neuralgia}

Results comparing perceptions of patients and physicians are summarized in Table 3 . While $83 \%$ of primary care physicians and $78 \%$ of neurologists said that they talked about the cause of pain after shingles with postherpetic neuralgia patients, $70 \%$ of patients said their doctor had this discussion with them. When asked if their physician had specifically told them that their diagnosis was "postherpetic neuralgia," 55\% of patients answered affirmatively. Sixty-four percent of primary care physicians 
Table 3 Summary of physician and patient perceptions on PHN care

\begin{tabular}{|c|c|c|c|c|}
\hline & $\begin{array}{l}P C P \\
(n=150)\end{array}$ & $\begin{array}{l}\text { Neurologist } \\
(n=76)\end{array}$ & $\begin{array}{l}\text { Patient } \\
(n=142)\end{array}$ & $P$ value* \\
\hline Physician discussed cause of pain after shingles & & & & $<0.001$ \\
\hline Disagree & $0.7 \%$ & $0.0 \%$ & $22.5 \%$ & \\
\hline Neutral & $16.7 \%$ & $22.4 \%$ & $7.7 \%$ & \\
\hline Agree & $82.7 \%$ & $77.6 \%$ & $69.7 \%$ & \\
\hline Physician specifically told the patient they had "PHN" & & & & $<0.001$ \\
\hline Disagree & $1.3 \%$ & $1.3 \%$ & $28.2 \%$ & \\
\hline Neutral & $34.2 \%$ & $21.1 \%$ & $16.9 \%$ & \\
\hline Agree & $64.4 \%$ & $77.6 \%$ & $54.9 \%$ & \\
\hline Patients are aware of the duration of $\mathrm{PHN}$ & & & & $<0.001$ \\
\hline Disagree & $1.3 \%$ & $3.9 \%$ & $21.1 \%$ & \\
\hline Neutral & $33.3 \%$ & $43.4 \%$ & $5.6 \%$ & \\
\hline Agree & $65.3 \%$ & $52.6 \%$ & $73.2 \%$ & \\
\hline Patients understand what to expect from treatment & & & & $<0.001$ \\
\hline Disagree & $3.4 \%$ & $0.0 \%$ & $27.5 \%$ & \\
\hline Neutral & $54.4 \%$ & $53.9 \%$ & $9.2 \%$ & \\
\hline Agree & $42.3 \%$ & $46.1 \%$ & $63.4 \%$ & \\
\hline The treatment is able to control pain** & & & & $<0.001$ \\
\hline Disagree & $2.0 \%$ & $0.0 \%$ & $32.4 \%$ & \\
\hline Neutral & $82.3 \%$ & $81.3 \%$ & $36.6 \%$ & \\
\hline Agree & $15.6 \%$ & $18.7 \%$ & $31.0 \%$ & \\
\hline Physicians discuss potential treatment side effects & & & & $<0.001$ \\
\hline Disagree & $0.0 \%$ & $1.3 \%$ & $23.2 \%$ & \\
\hline Neutral & $42.2 \%$ & $32.0 \%$ & $38.7 \%$ & \\
\hline Agree & $57.8 \%$ & $66.7 \%$ & $38.0 \%$ & \\
\hline Patients are aware of potential treatment side effects & & & & $<0.001$ \\
\hline Disagree & $1.4 \%$ & $1.3 \%$ & $9.9 \%$ & \\
\hline Neutral & $45.9 \%$ & $35.5 \%$ & $23.2 \%$ & \\
\hline Agree & $52.7 \%$ & $63.2 \%$ & $66.9 \%$ & \\
\hline Patients discuss treatment side effects with physicians & & & & $<0.001$ \\
\hline Never or rarely & $1.3 \%$ & $0.0 \%$ & $17.6 \%$ & \\
\hline Sometimes & $15.3 \%$ & $7.9 \%$ & $31.0 \%$ & \\
\hline Often or always & $83.3 \%$ & $92.1 \%$ & $51.4 \%$ & \\
\hline Patients discuss quality of life issues with physicians & & & & $<0.001$ \\
\hline No & $25.2 \%$ & $13.3 \%$ & $58.5 \%$ & \\
\hline Yes & $74.8 \%$ & $86.7 \%$ & $41.5 \%$ & \\
\hline Satisfaction with current $\mathrm{PHN}$ treatments & & & & $<0.001$ \\
\hline Dissatisfied & $2.7 \%$ & $0.0 \%$ & $15.5 \%$ & \\
\hline Neutral & $91.3 \%$ & $92.1 \%$ & $62.0 \%$ & \\
\hline Satisfied & $6.0 \%$ & $7.9 \%$ & $22.5 \%$ & \\
\hline Follow-up scheduled in I-3 months & & & & $<0.001$ \\
\hline No & $18.7 \%$ & $9.2 \%$ & $40.1 \%$ & \\
\hline Yes & $81.3 \%$ & $90.8 \%$ & $59.9 \%$ & \\
\hline More patient information on $\mathrm{PHN}$ is needed & & & & $<0.001$ \\
\hline Disagree & $20.0 \%$ & $36.8 \%$ & $22.5 \%$ & \\
\hline Neutral & $60.7 \%$ & $53.9 \%$ & $43.7 \%$ & \\
\hline Agree & $19.3 \%$ & $9.2 \%$ & $33.8 \%$ & \\
\hline
\end{tabular}

Notes: *A Chi-square test was conducted on the combined physician versus patient responses for each option; **for this selection, physicians rated their confidence, and patients rated treatment effectiveness.

Abbreviations: PCP, primary care physician; PHN, postherpetic neuralgia.

and $78 \%$ of neurologists indicated that they specifically told patients that they had "postherpetic neuralgia." With respect to communicating how long postherpetic neuralgia would last, $65 \%$ of primary care physicians and $53 \%$ of neurologists agreed that they do discuss this, while $73 \%$ of patients agreed that their physicians had talked about this with them. Finally, $63 \%$ of patients felt they understood what to expect from treatment, while only $42 \%$ of primary care physicians and $46 \%$ of neurologists felt patients understood this. 


\section{Opinions on treatment efficacy and safety}

Physicians were doubtful about the ability of treatment to control pain associated with postherpetic neuralgia, with only $16 \%$ of primary care physicians and $19 \%$ of neurologists ranking themselves as very confident that the chosen treatment would control a patient's pain; however, $31 \%$ of patients said their medications were effective for pain control. With respect to physician discussion of potential treatment side effects, $58 \%$ of primary care physicians and $67 \%$ of neurologists claimed to discuss this with their patients; only $38 \%$ of patients recalled this being discussed. Patient awareness of side effects was similar, as $53 \%$ of primary care physicians and $63 \%$ of neurologists thought patients were aware of medication side effects; however, $67 \%$ of patients said that they were aware of potential side effects associated with their medication. Only $6 \%$ of primary care physicians and $8 \%$ of neurologists were satisfied with currently available postherpetic neuralgia treatments, but $23 \%$ of patients said they were satisfied.

Of interest, a majority of physicians perceived that their patients discuss their treatment side effects $(83 \%$ of primary care physicians and $92 \%$ of neurologists) and quality of life issues $(75 \%$ of primary care physicians and $87 \%$ of neurologists), but the patients claimed that they may not always do so. Only $51 \%$ of patients said that they often or always discussed side effects with their physician and $42 \%$ discussed quality of life issues.

\section{Follow-up and education}

Although $81 \%$ of primary care physicians and $91 \%$ of neurologists said they scheduled a follow-up visit for patients in 1-3 months, only $60 \%$ of patients said they were reevaluated that quickly, and $25 \%$ said there was no follow-up visit scheduled. One-third of patients thought there was a need for more patient education on postherpetic neuralgia, but only $19 \%$ of primary care physicians and $9 \%$ of neurologists thought this was a need.

\section{Discussion}

Postherpetic neuralgia can be a debilitating condition that takes a toll on a patient's quality of life. Available guidelines suggest effective agents based on current evidence but do not provide a specific algorithm for management, leaving choice of agents and timing of evaluation to physician discretion. Physician-patient communication about the efficacy of postherpetic neuralgia management is therefore a crucial part of optimizing care. Recent studies in other disease states have demonstrated that physicians and patients perceive their interactions differently, and this may lead to misunderstandings about diagnosis, the severity of a condition, and therapeutic risks and benefits. ${ }^{8,9}$ We sought to evaluate the practice patterns of physicians caring for patients with postherpetic neuralgia, including the barriers to optimal care, and to discover how these patients viewed their care.

A number of communication gaps came to light in our study. The percentage of physicians who said they talked about the cause of postherpetic neuralgia and specifically told patients that they had postherpetic neuralgia was higher than the percentage of patients who said those issues were discussed with them. These disparities could result from a number of situations. It may be that physicians think they are discussing these issues with patients and they are not, or that physicians are talking about the etiology of postherpetic neuralgia and its diagnosis in terms patients cannot understand. Interestingly, the percentage of patients who said they had been told how long postherpetic neuralgia would last and what to expect from treatment was higher than the percentage of physicians who said they discussed this. The lower percentage of physicians who thought they discussed these issues brings up the question of the importance placed by physicians on educating patients about these issues, although they in fact seem to be discussing this with patients.

A clear lapse in communication was seen around treatment efficacy and safety. Far fewer physicians were confident in their ability to treat postherpetic neuralgia and were satisfied with available therapies compared with the percentage of patients who felt their medication was effective and were happy with the current treatments. It may be that physicians have more memory of patients with difficult-to-treat postherpetic neuralgia or who frequently complain about their medications and thus physician opinion is negatively skewed. Also, patient satisfaction could potentially be increased due to switching to more effective medications through the course of the illness. Physicians thought that they discussed potential treatment side effects more often than patients recalled holding these discussions. Interestingly, almost twice as many patients said they were aware of potential treatment side effects than said that physicians discussed this with them. Patients may not recall having a discussion on side effects with their physicians, or this may be related to our patient sample, which was computer-literate and may have searched for this information on their own.

Of concern is the disparity concerning how often patients discuss side effects and quality of life issues with their physicians. Based on these responses, physicians may 
be unaware of the times when patients may be holding information back from their physicians, potentially leading to gaps in proper care and treatment satisfaction.

A significant disparity also exists between physician and patient perceptions of follow-up care. A large majority of physicians thought they scheduled follow-up care within 1-3 months, but only two-thirds of patients said they were re-evaluated in that time frame, and one quarter of patients said they had no follow-up at all. Physician self-assessment of follow-up care of postherpetic neuralgia patients may lead to improved outcomes if patients are seen more frequently.

Finally, it is clear that patients want more education, and physicians are less likely to perceive this need. This result particularly highlights the gap between physician conception of interaction with patients and the reality of the situation.

One of the main limitations to this study is that the surveyed patients were not nested to the physician sample, so we cannot directly measure if the physicians' perceptions hold true to the patients they actually manage. Future studies on these gaps in communication would be needed to link such perceptions of care directly. Additionally, because the patient-survey link was posted on a medical education website, the presumption might be that patients responding to the survey were computer-literate and may have been actively seeking information about their condition. Therefore, they may have not been representative of the general population of patients with postherpetic neuralgia. If patients were on the website seeking information about their condition, there may have been bias in that these patients were not completely satisfied with the care offered by their managing physician. Another possibility is that information obtained from the referring website may have been misremembered and misattributed to an interaction with a physician. Physicians and patients received nominal compensation for their completion of the survey, which could have created a small participation bias.

These gaps in physician-patient communication and perception are clear barriers to optimizing care of patients with postherpetic neuralgia. The development of office protocols may help alleviate some of these problems, which could potentially result from a lack of follow-up care due to miscommunication. Physician education in small group sessions may be useful to facilitate discussions and practice communication techniques. These techniques may include using simpler, less scientific language, speaking more slowly to give patients time to digest information, speaking more loudly for patients with hearing difficulties, and providing take-home information in a legible format written at a patient level. Physicians may find that short videos are helpful for some patients. In addition, physicians can help patients become better communicators by encouraging them to write down what they would like to discuss prior to the visit and by bringing a companion who can also listen to instructions.

\section{Acknowledgments}

We would like to thank Barbara Martin for her assistance with understanding the current literature involving postherpetic neuralgia management. These studies were supported by Depomed Inc.

\section{Disclosure}

The authors report no conflicts of interest in this work.

\section{References}

1. Johnson RW, Wasner G, Saddier P, Baron R. Herpes zoster and postherpetic neuralgia: Optimizing management in the elderly patient. Drugs Aging. 2008;25(12):991-1006.

2. Harpaz R, Ortega-Sanchez IR, Seward JF. Advisory Committee on Immunization Practices (ACIP) Centers for Disease Control and Prevention (CDC). Prevention of herpes zoster: Recommendations of the advisory committee on immunization practices (ACIP). MMWR Recomm Rep. 2008;57(RR-5):1-30.

3. Dubinsky RM, Kabbani H, El-Chami Z, Boutwell C, Ali H. Quality Standards Subcommittee of the American Academy of Neurology. Practice parameter: Treatment of postherpetic neuralgia: An evidencebased report of the quality standards subcommittee of the American Academy of Neurology. Neurology. 2004;63(6):959-965.

4. Bennett GJ, Watson CP. Herpes zoster and postherpetic neuralgia: Past, present and future. Pain Res Manag. 2009;14(4):275-282.

5. Oster G, Harding G, Dukes E, Edelsberg J, Cleary PD. Pain, medication use, and health-related quality of life in older persons with postherpetic neuralgia: Results from a population-based survey. J Pain. 2005;6(6): 356-363.

6. Gore M, Dukes E, Rowbotham DJ, Tai KS, Leslie D. Clinical characteristics and pain management among patients with painful peripheral neuropathic disorders in general practice settings. Eur J Pain. 2007;11(6):652-664

7. Hurley LP, Harpaz R, Daley MF, et al. National survey of primary care physicians regarding herpes zoster and the herpes zoster vaccine. J Infect Dis. 2008;197 Suppl 2:S216-S223.

8. Allegretti A, Borkan J, Reis S, Griffiths F. Paired interviews of shared experiences around chronic low back pain: Classic mismatch between patients and their doctors. Fam Pract. 2010;27(6):676-683.

9. Olson DP, Windish DM. Communication discrepancies between physicians and hospitalized patients. Arch Intern Med. 2010;170(15):1302-1307. 


\section{Appendix A}

\section{Physician survey items}

Case

Michael is a 68-year-old African-American male who presents to your office with pain in the left face. He had acute herpes zoster 9 months ago with the rash located in the V1 distribution and the course was complicated by corneal involvement. Antiviral therapy and acetaminophen with codeine were initiated about a week after the onset of the rash. The rash resolved approximately 4 months ago, but he was left with a constant severe pain, which was rated 7/10 and described as burning with intermittent sharp, shooting pains in his left forehead and eye. He is not sleeping well because his pain frequently awakens him. On examination, there is scarring of the skin over the left forehead with loss of sensation to light touch and temperature in the area of scarring. You diagnose him with postherpetic neuralgia.

1. How soon would you plan to see this patient after starting therapy? (select only one)

\begin{tabular}{|c|l|}
\hline$\square$ & Generally, no follow-up is scheduled \\
\hline$\square$ & Every 1-3 months until symptoms resolve \\
\hline$\square$ & Every 4-6 months until symptoms resolve \\
\hline$\square$ & Other (please specify): \\
\hline
\end{tabular}

2. How confident are you that your initial treatment choice will control this patient's pain?

\begin{tabular}{|l|l|l|l|l|l|l|}
\hline 1 & 2 & 3 & 4 & 5 & 6 & 7 \\
\hline \multicolumn{4}{|c|}{ not at all confident } \\
\hline
\end{tabular}

3. Overall, how satisfied are you with currently available treatments for PHN? (select only one)

\begin{tabular}{|l|l|l|l|l|l|l|}
\hline$\square$ & $\square$ & $\square$ & $\square$ & $\square$ & $\square$ & $\square$ \\
\hline $\begin{array}{l}\text { Extremely } \\
\text { dissatisfied }\end{array}$ & $\begin{array}{l}\text { Very } \\
\text { dissatisfied }\end{array}$ & Dissatisfied & $\begin{array}{l}\text { Somewhat } \\
\text { satisfied }\end{array}$ & Satisfied & $\begin{array}{l}\text { Very } \\
\text { satisfied }\end{array}$ & $\begin{array}{l}\text { Extremely } \\
\text { satisfied }\end{array}$ \\
\hline
\end{tabular}

4. Please rate your level of agreement with each of the following statements. (select only one for each)

\begin{tabular}{|c|c|c|c|c|c|c|c|}
\hline \multirow[b]{2}{*}{$\begin{array}{l}\text { I usually explain the cause of the pain to my patients before } \\
\text { I begin treating it. }\end{array}$} & \multicolumn{2}{|c|}{$\begin{array}{l}\text { Strongly } \\
\text { disagree }\end{array}$} & \multicolumn{3}{|c|}{ Neutral } & \multicolumn{2}{|r|}{$\begin{array}{c}\text { Strongly } \\
\text { agree }\end{array}$} \\
\hline & 1 & 2 & 3 & 4 & 5 & 6 & 7 \\
\hline My patients are aware that PHN may last indefinitely. & 1 & 2 & 3 & 4 & 5 & 6 & 7 \\
\hline $\begin{array}{l}\text { Based on my explanation, my patients understand when they will } \\
\text { begin to see pain relief from the medications I prescribe. }\end{array}$ & 1 & 2 & 3 & 4 & 5 & 6 & 7 \\
\hline $\begin{array}{l}\text { My patients are aware of the potential side effects associated with } \\
\text { the medications I prescribe for their PHN. }\end{array}$ & 1 & 2 & 3 & 4 & 5 & 6 & 7 \\
\hline $\begin{array}{l}\text { My patients are likely to discuss with me the side effects they } \\
\text { experience with their PHN medications. }\end{array}$ & 1 & 2 & 3 & 4 & 5 & 6 & 7 \\
\hline $\begin{array}{l}\text { When I diagnose patients with PHN, I typically tell them they } \\
\text { have "post herpetic neuralgia." }\end{array}$ & 1 & 2 & 3 & 4 & 5 & 6 & 7 \\
\hline My patients need more information about PHN. & 1 & 2 & 3 & 4 & 5 & 6 & 7 \\
\hline
\end{tabular}


5. How often do your patients discuss the side effects of their PHN medication with you? (select only one)

\begin{tabular}{|l|l|l|l|l|}
\hline $\begin{array}{l}\square \text { Never } \\
(0 \% \text { of the time })\end{array}$ & $\begin{array}{l}\square \text { Rarely } \\
(<25 \% \text { of the time })\end{array}$ & $\begin{array}{l}\square \text { Sometime } \\
(25 \%-50 \% \text { of the time })\end{array}$ & $\begin{array}{l}\square \text { Often } \\
(51 \%-75 \% \text { of the time })\end{array}$ & $\begin{array}{l}\square \text { Nearly always } \\
(76 \%-100 \% \text { of the time })\end{array}$ \\
\hline
\end{tabular}

6. How often do your patients discuss how PHN and its treatments affect their quality of life? (select only one)

\begin{tabular}{|l|l|l|l|l|}
\hline $\begin{array}{l}\text { Never } \\
(0 \% \text { of the time })\end{array}$ & $\begin{array}{l}\square \text { Rarely } \\
(<25 \% \text { of the time })\end{array}$ & $\begin{array}{l}\square \text { Sometime } \\
(25 \%-50 \% \text { of the time })\end{array}$ & $\begin{array}{l}\square \text { Often } \\
(51 \%-75 \% \text { of the time })\end{array}$ & $\begin{array}{l}\square \text { Nearly always } \\
(76 \%-100 \% \text { of the time })\end{array}$ \\
\hline
\end{tabular}

7. Approximately how many patients do you see each week? /per week

8. Approximately what percentage of your patients has PHN? $\%$

Abbreviation: PHN, postherpetic neuralgia

\section{Appendix B}

\section{Patient survey items}

1. Please rate your level of pain after shingles at its worst (choose one number)

\begin{tabular}{|l|l|l|l|l|l|l|l|l|l|l|}
\hline No pain & $\begin{array}{l}\text { Pain as bad as } \\
\text { you can imagine }\end{array}$ \\
\hline 0 & 1 & 2 & 3 & 4 & 5 & 6 & 7 & 8 & 9 & 10 \\
\hline
\end{tabular}

2. Please rate your level of pain now (choose one number)

\begin{tabular}{|l|l|l|l|l|l|l|l|l|l|l|}
\hline No pain & \multicolumn{1}{c|}{$\begin{array}{l}\text { Pain as bad as } \\
\text { you can imagine }\end{array}$} \\
\hline 0 & 1 & 2 & 3 & 4 & 5 & 6 & 7 & 8 & 9 & 10 \\
\hline
\end{tabular}

3. What type of physician prescribed medication(s) for your pain that occurred after the shingles rash? (select only one)

\begin{tabular}{|l|l|}
\hline$\square$ & Family medicine \\
\hline$\square$ & Internist \\
\hline$\square$ & Neurologist \\
\hline$\square$ & Pain specialist \\
\hline$\square$ & Other (please specify): \\
\hline
\end{tabular}

4. At the time your physician gave you a prescription for the pain, did your physician discuss any of these topics with you? (select only one for each)

\begin{tabular}{|l|l|l|l|}
\hline The cause of the pain after your shingles & $\square$ Yes & $\square$ No & $\square$ Don't remember \\
\hline What to expect from medication used to manage the pain after shingles & $\square$ Yes & $\square$ No & $\square$ Don't remember \\
\hline That pain after shingles may remain for a long time & $\square$ Yes & $\square$ No & $\square$ Don't remember \\
\hline
\end{tabular}

5. Did your physician tell you specifically that you had "post-herpetic neuralgia"?

\begin{tabular}{|l|l|l|}
\hline$\square$ Yes & $\square$ No & $\square$ Don’t remember \\
\hline
\end{tabular}


6. How soon after you started taking your medication(s) for the pain after the shingles did your physician ask you to schedule a follow-up appointment? (select only one)

\begin{tabular}{|l|l|}
\hline$\square$ & No follow-up was scheduled \\
\hline$\square$ & Within the 1-3 months after starting my medication \\
\hline$\square$ & Within the first 4-6 months after starting my medication \\
\hline$\square$ & Other (please specify): \\
\hline
\end{tabular}

7. Have you ever discussed how your treatment of pain after shingles affects your quality of life with your doctor?

\begin{tabular}{|l|l|}
\hline$\square$ & Yes \\
\hline$\square$ & No \\
\hline
\end{tabular}

8. Overall, how effective at relieving your pain was the medication(s) your doctor prescribed initially for your pain after shingles? (select only one)

\begin{tabular}{|l|l|l|l|l|l|}
\hline$\square$ & $\square$ & $\square$ & $\square$ & $\square$ & $\square$ \\
\hline Not at all effective & Not very effective & $\begin{array}{l}\text { Somewhat } \\
\text { effective }\end{array}$ & Somewhat effective & Very effective & $\begin{array}{l}\text { Extremely } \\
\text { effective }\end{array}$ \\
\hline
\end{tabular}

9. Overall, how satisfied were you with the medication(s) you received for the pain after shingles? (select only one)

\begin{tabular}{|l|l|l|l|l|l|l|}
\hline$\square$ & $\square$ & $\square$ & $\square$ & $\square$ & $\square$ & $\square$ \\
\hline $\begin{array}{l}\text { Extremely } \\
\text { dissatisfied }\end{array}$ & $\begin{array}{l}\text { Very } \\
\text { dissatisfied }\end{array}$ & Dissatisfied & $\begin{array}{l}\text { Somewhat } \\
\text { satisfied }\end{array}$ & Satisfied & $\begin{array}{l}\text { Very } \\
\text { satisfied }\end{array}$ & $\begin{array}{l}\text { Extremely } \\
\text { satisfied }\end{array}$ \\
\hline
\end{tabular}

10. Please rate your level of agreement with these statements about your pain after shingles (select only one for each)

\begin{tabular}{|l|l|l|l|l|l|l|l|}
\hline & $\begin{array}{l}\text { Strongly } \\
\text { disagree }\end{array}$ & \multicolumn{3}{c|}{ Neutral } \\
\hline
\end{tabular}

11. Please rate your level of agreement with these statements about your pain after shingles (select only one for each)

\begin{tabular}{|l|l|l|l|l|l|l|l|}
\hline & $\begin{array}{l}\text { Strongly } \\
\text { disagree }\end{array}$ & \multicolumn{5}{|c|}{$\begin{array}{c}\text { Neutral } \\
\text { agree }\end{array}$} \\
\hline I needed more information to manage my pain. & 1 & 2 & 3 & 4 & 5 & 6 & 7 \\
\hline $\begin{array}{l}\text { My doctor clearly explained the possible side effects of my pain } \\
\text { medications. }\end{array}$ & 1 & 2 & 3 & 4 & 5 & 6 & 7 \\
\hline
\end{tabular}

Journal of Pain Research

\section{Publish your work in this journal}

The Journal of Pain Research is an international, peer-reviewed, open access, online journal that welcomes laboratory and clinical findings in the fields of pain research and the prevention and management of pain. Original research, reviews, symposium reports, hypothesis formation and commentaries are all considered for publication.

The manuscript management system is completely online and includes a very quick and fair peer-review system, which is all easy to use. Visit http://www.dovepress.com/testimonials.php to read real quotes from published authors.
Dovepress 